University of Nebraska - Lincoln

DigitalCommons@University of Nebraska - Lincoln

Faculty Publications from the Harold W. Manter Laboratory of Parasitology

10-1952

\title{
Hydatid Disease in Boreal Regions
}

Robert L. Rausch

University of Washington, rausch@uw.edu

Follow this and additional works at: https://digitalcommons.unl.edu/parasitologyfacpubs

Part of the Parasitology Commons

Rausch, Robert L., "Hydatid Disease in Boreal Regions" (1952). Faculty Publications from the Harold W. Manter Laboratory of Parasitology. 492.

https://digitalcommons.unl.edu/parasitologyfacpubs/492

This Article is brought to you for free and open access by the Parasitology, Harold W. Manter Laboratory of at DigitalCommons@University of Nebraska - Lincoln. It has been accepted for inclusion in Faculty Publications from the Harold W. Manter Laboratory of Parasitology by an authorized administrator of DigitalCommons@University of Nebraska - Lincoln. 


\section{HYDATID DISEASE IN BOREAL REGIONS}

\section{Robert Rausch*}

H YDATID disease, or echinococcosis, is one of the more important helminthic diseases which may be transmitted from lower mammals to man. It is caused by tapeworms of the genus Ecbinococcus (Rudolphi, 1810), which are cosmopolitan in their distribution. A serious threat to human health exists wherever there is contact between man and infected carnivores.

It is the purpose of this paper to review the status of hydatid disease in the boreal regions of the world. Its importance has long been recosnized in Eurasian countries, but only during recent years have investigators added anything significant to the knowledge of hydatid disease in North America. There is need to disseminate up-to-date information among medical workers in Canada and Alaska, where the disease is endemic in northern regions having a large aboriginal population. Therefore, particular emphasis will be placed on the situation in boreal North America.

Hydatid disease is defined as the infection of man by the larval stage of Echinococcus granulosus (Batsch, 1786). However, six species of Echinococcus are currently considered valid, and all may be capable of infecting man. The taxonomy of tapeworms of this genus is based on morphological characters of the adult stage. There is reason to believe that other factors should be considered, and that normal variation in the structure of the adult worm should be investigated in order to have a better concept of what constitutes specific differences.

In the northern hemisphere, so far as I am aware, only two species exist. The common species is E. granulosus, but it is apparent that another, at least immunologically distinct, species also occurs in Siberia and on St. Lawrence Island in the Bering Sea.

The life cycle of the various species of Echinococcus is a simple one, involving but two hosts: the final host, which harbours the adult parasite, and the intermediate host, which harbours the larval stage (Fig. 1). The adult parasite occurs in the small intestine of carnivores, and ordinarily is very numerous. Canine animals are the only important final host-group, but in some parts of the world feline animals are also included (namely, lion, puma, and jaguarundi cat). Ungulates are the main intermediate host-group though a few other mammals, including man, may be infected. For the species of Echinococcus found in Siberia and on St. Lawrence Island voles of the genera Microtus and Clethrionomys serve as the intermediate host.

The adult parasite is remarkably small when the size of the larval stage is considered. Alaskan specimens collected from dogs, wolves, and red and

*Arctic Health Research Center, U.S. Public Health Service, F.S.A., Anchorage, Alaska. 


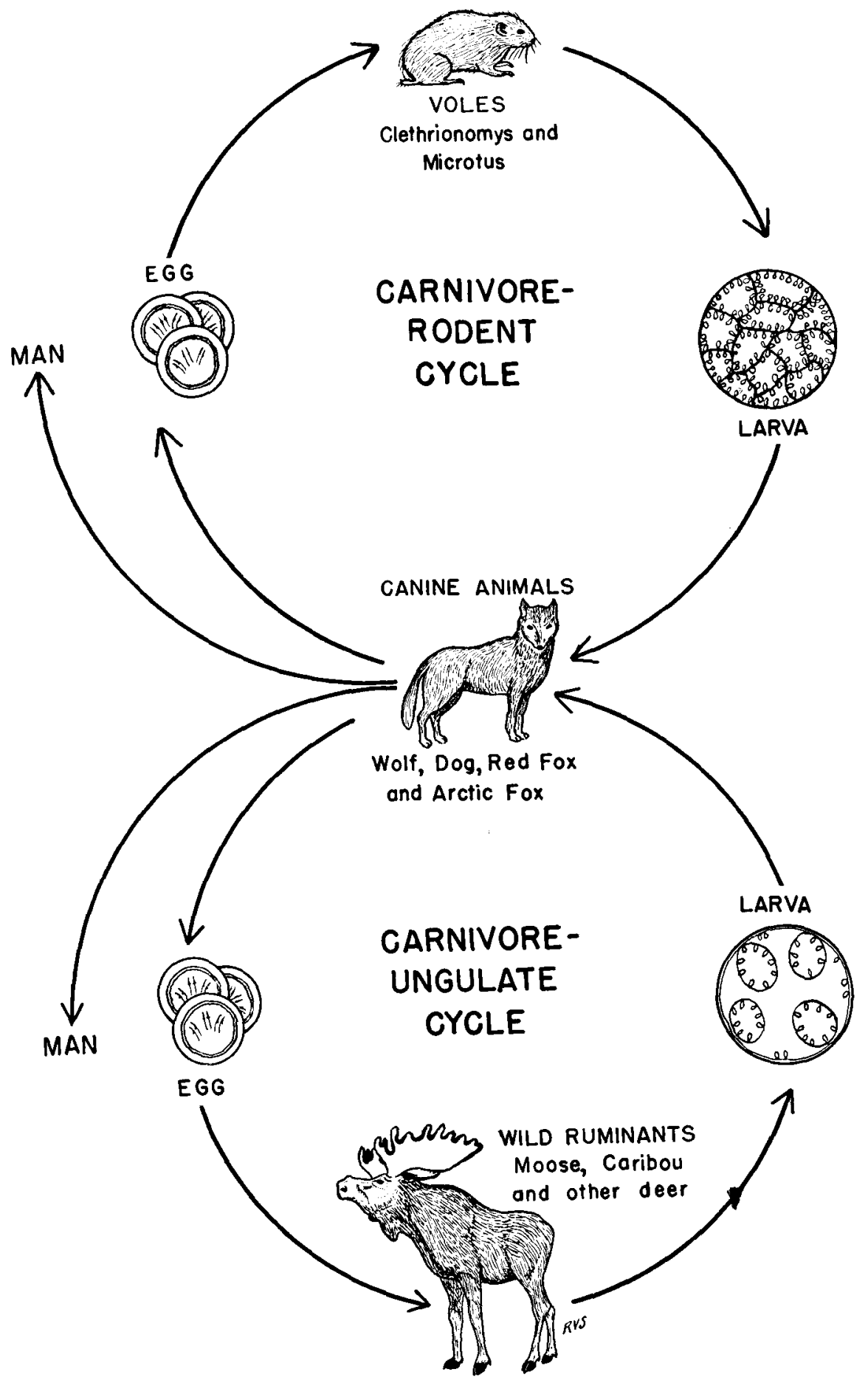

Fig. 1. Schematic drawing of life cycles of two species of Echinococcus, demonstrating host relarionships as they occur naturally in North America. 
arctic foxes measure in length from one to four mm. (Rausch, 1952). The strobila, or body, of the parasite consists of a scolex and three to four segments (Fig. 2). The scolex is provided with four suckers and an eversible rostellum

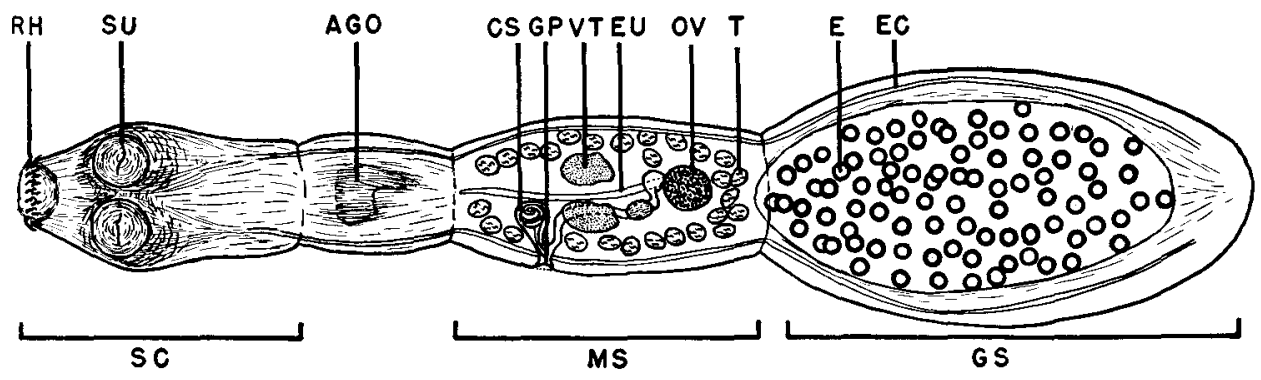

Fig. 2. Anatomy of an adult cestode of the genus Ecbinococcus. SC, scolex; RH, rostellar hooks; SU, sucker; AGO, Anlagen of genital organs; MS, mature segment; CS, cirrus sac; $\mathrm{GP}$, genital pore; VT, vitelline gland; $\mathrm{EU}$, carly uterus; OV, ovary; T, testis; GS, gravid segment; $\mathrm{F}$, egg; EC, excretory canal. Specimen from arctic fox experimentally infected with material of St. Lawrence Island origin. Magnification approximately $60 \mathrm{X}$; original specimen $2.06 \mathrm{~mm}$. long.

armed with a double row of hooks (about 30 in number) by which the strobila attaches itself to the host intestine. The first one or two segments following the scolex are not well differentiated, but contain rapidly-developing reproductive organs. The next segment contains mature (both male and female) reproductive organs. The terminal segment contains only a gravid uterus. Because of the great capacity of the larval worm for asexual reproduction, very heavy infections in the final host are usual; in some cases the cestodes cover nearly the entire mucosal surface of the host intestine (Figs. 3-4).

Egg production begins a few weeks after the ingestion of the larval stage by the final host. As the terminal segments become gravid, they are shed and eliminated in the feces of the host. The segment then disintegrates rapidly, freeing the eggs. There is some disagreement as to the minimum time required before the eggs appear in the excreta of the host animal. Fiebiger (1947) considered 70 days the minimum time. Mönnig (1938) stated that the worms mature in six to seven weeks. According to observations made in the laboratory of the Arctic Health Research Center, eggs may appear in the feces of experimentally-infected arctic foxes in about four weeks (St. Lawrence Island form of Echinococcus). Since each gravid segment contains roughly 200 eggs, it is evident that animals with heavy infections daily eliminate great numbers of eggs. These eggs are the source of infection for the various intermediate-host species, of which man is one.

Each egg contains an onchosphere, or embryo, possessing six hooks. When the eggs are ingested by a mammal capable of serving as the intermediate host, the egg shell is ruptured by the digestive processes. The liberated onchosphere then perforates the intestinal wall and enters the blood stream.

Because of the arrangement of the visceral circulation, the onchospheres are carried to the liver first. In man 60 to 75 per cent localize in this organ, 
but few or none are found in the liver of some of the other intermediate hosts. However, in voles infected with the St. Lawrence Island larvae I have not so far seen localization in any organ other than the liver. If the onchospheres succeed in passing through the liver, they are carried into the right auricle of the heart, and thence into the right ventricle from which they pass to the lungs. In wild ungulates nearly all larvae are found in the lungs; in man less than 20 per cent localize in this organ. Any onchospheres which pass through the lungs and return to the heart, go into the systemic circulation from the left ventricle. These are relatively few, but in man they account for the larvae occurring in the brain, bone marrow, kidney, and elsewhere.

After the onchosphere of $E$. gramulosus localizes in a given organ, growth takes place rapidly. Initial development gives rise to a solid mass in which a central cavity soon appears. A germinal membrane is produced, which lines the entire cavity. This membrane is in direct contact with a thin connective tissue capsule separating it from normal host tissue. The connective tissue wall is a product of the host tissue-reaction. The vesicle-like larva, commonly known as the hydatid cyst, is turgid and is filled with a whitish, rather opalescent fluid. The larva grows steadily and scolices are produced in great numbers by the germinal membrane. Secondary germinal vesicles may arise inside the first, and these also produce scolices asexually. Dew (1925) gives an excellent discussion of larval development. In man the larvae may reach a great size, for example, Dungal (1946) described a larval vesicle attached to the liver of an Icelandic woman which was $50 \mathrm{~cm}$. in diameter and contained 16 litres of fluid.

The pathogenicity of Ecbinococcus infection involving E. granulosus is directly related to the locus of larval development in the body of the intermediate host. In the liver larvae may remain undiagnosed until accidentally discovered at autopsy since they commonly do not give rise to any clinical symptoms unless they become exceedingly large or unless they rupture; in the latter case larval growth in the peritoneal cavity may be extensive. Larvae in the lungs may not cause any recognizable effect. If, as sometimes happens, they rupture into a bronchus, recovery may be spontaneous, but more often complications arise. Hydatid disease elsewhere, such as in the kidney or spleen, is generally serious. In the brain the symptoms may resemble those caused by a fibrous tumour. Seizures and paralysis may occur, and there may be osteoporosis of the skull bones. If larvae reach the bone marrow, their growth causes gradual bone destruction and eventual pathological fracture; in many cases these fractures never heal. Localization in the myocardium may result in cardiac rupture. Spontaneous or traumatic (including surgical) rupture of the larva, wherever localized, may cause severe anaphylactic shock which in some cases results in death.

The literature on hydatid disease contains many references on pathogenicity, so it is necessary here only to mention that, in addition to the direct effects caused by the growth of the larva in the various organs, other indirect changes may occur. For instance, if the fluid contained in the larval vesicle escapes in small quantities various allergic reactions may follow; these may 
Rausch in Arctic: Journal of the Arctic Institute of North America (October 1952) 5(3).

Copyright 1952, Arctic Institute of North America. Used by permission.

HYDATID DISEASE IN BOREAL REGIONS

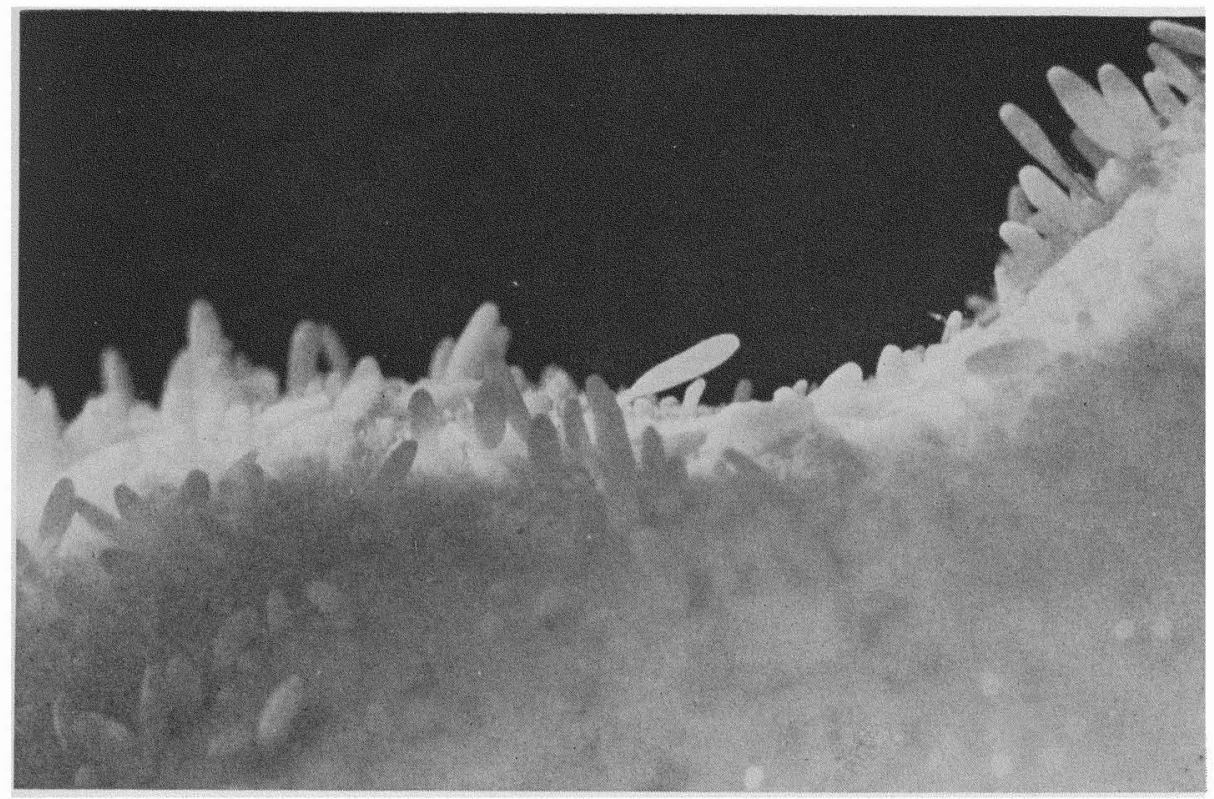

Fig. 3. Adult cestodes in situ in the intestine of a dog experimentally infected with larval material from an Alaskan moose. Photographed at magnification of $4.5 \mathrm{X}$.

Fig. 4.

Histological

section of gross specimen

shown in Fig. 3.

Considerable

damage to the

intestinal

mucosa has

resulted from

the massive

infection.

Photographed at

magnification of

$100 \mathrm{X}$.

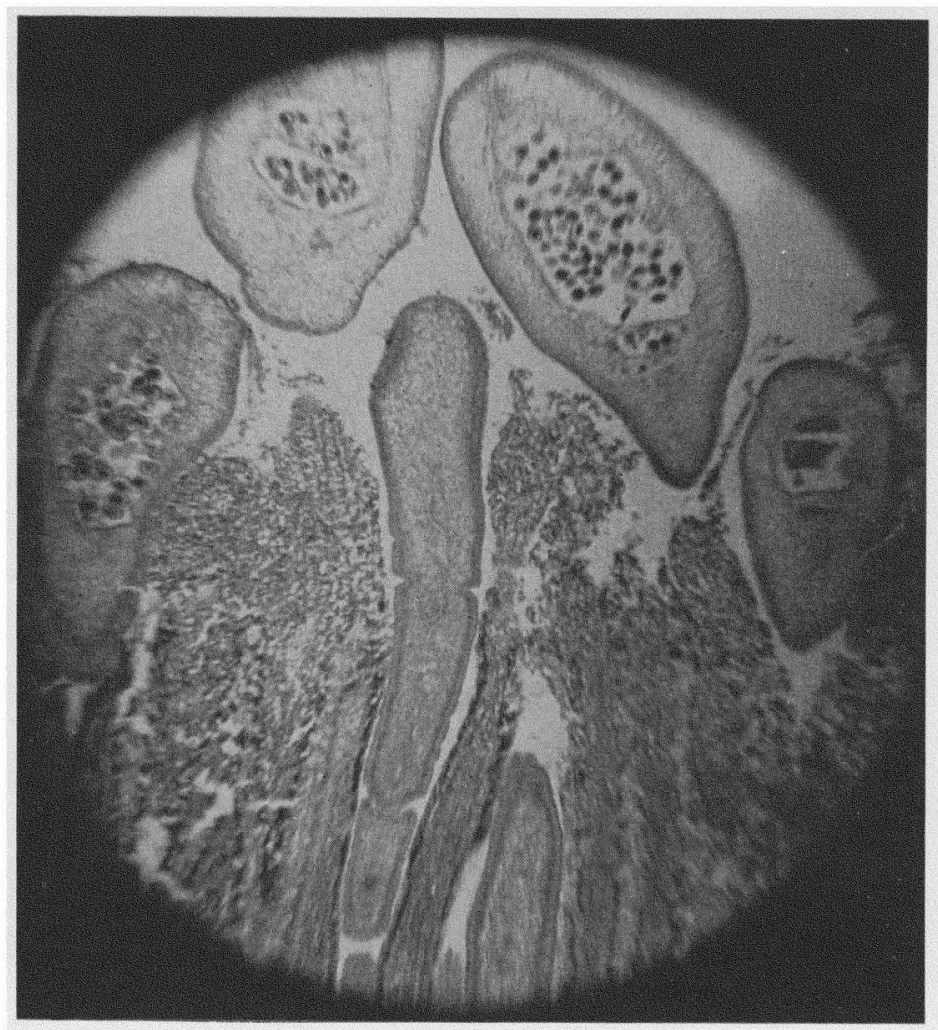




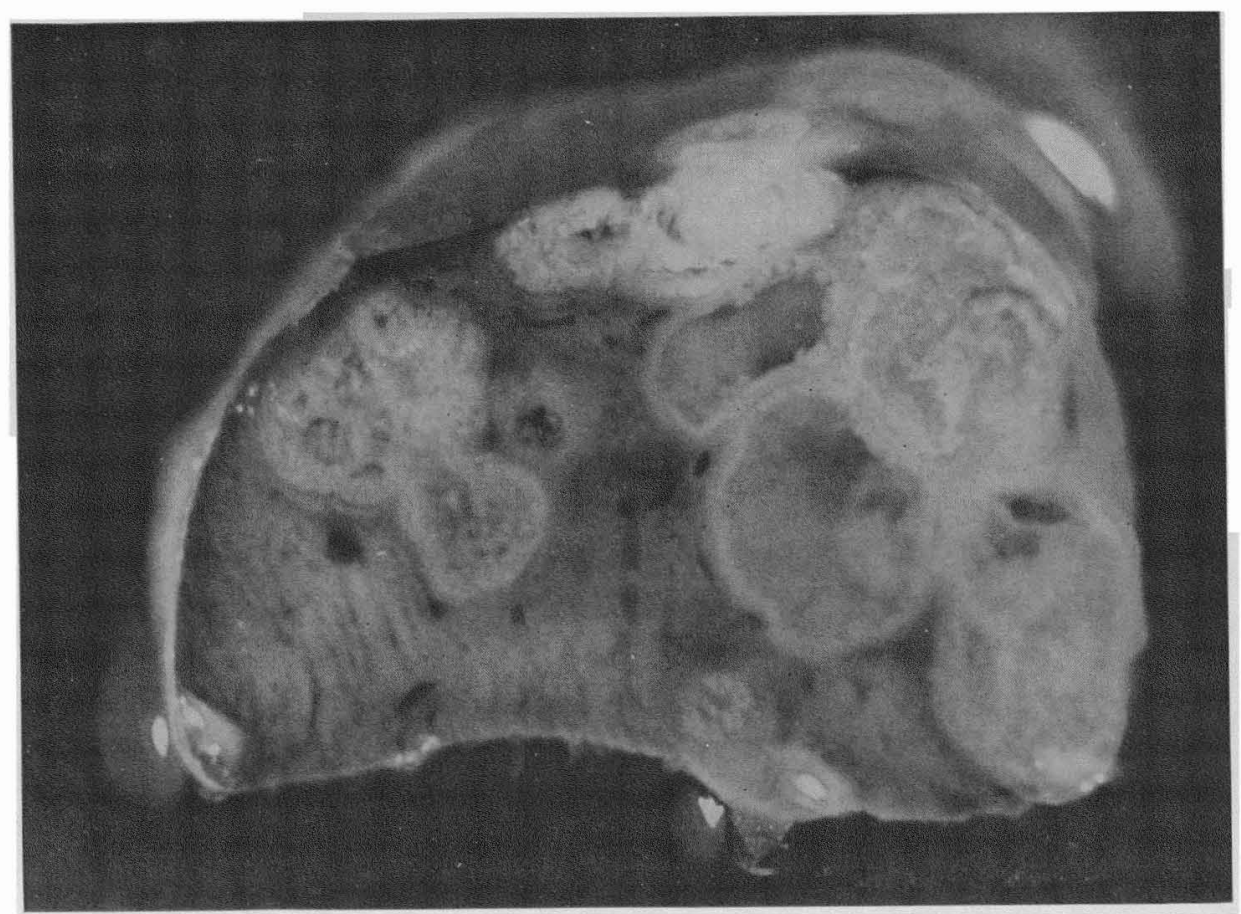

Fig. 5. Alveolar echinococcosis. Cross section of the liver of a common field vole, 166 days after experimental infection. Greatest width of this lobe actually $19 \mathrm{~mm}$. Total infected organ weighed 2 grams more than remainder of animal's body.

take several forms. Godfrey (1937: after Dew, 1928) listed a variety of cutaneous, gastro-intestinal, respiratory, cardiovascular, and nervous symptoms of anaphylaxis.

The larvae of E. granulosus appear to be essentially non-pathogenic in their natural mammal hosts. However, McTaggart Cowan (1944), writing on infected elk, stated that "Hydatids apparently reduce the vitality of the host to a marked degree." I do not believe that this is the case. In examinations of a considerable number of infected moose, including seven animals killed during the open hunting season in southern Alaska, I have seen nothing which would indicate that they were not in the best physical condition. It is true that the older a moose (and probably an elk as well) becomes, the greater the probability of its being infected. I would expect to find that nearly every aged moose in southern Alaska would harbour Echinococcus larvae. Naturally, aged animals would be the most likely to be in poor physical condition, but the Echinococcus larvae cannot be considered to contribute to this. I have removed as many as 18 larvae, ranging in size up to $80-90 \mathrm{~mm}$., from the lungs of a moose shot when apparently in excellent condition. The only pathological change I have seen in the lungs of infected moose is a slight proliferation of the connective tissue capsule which encloses the larval mass. I have never found larvae in any other organ in the moose, but de Vos and Allin (1949) reported them from the liver of three Ontario moose, two of which also had myocardial infections. 


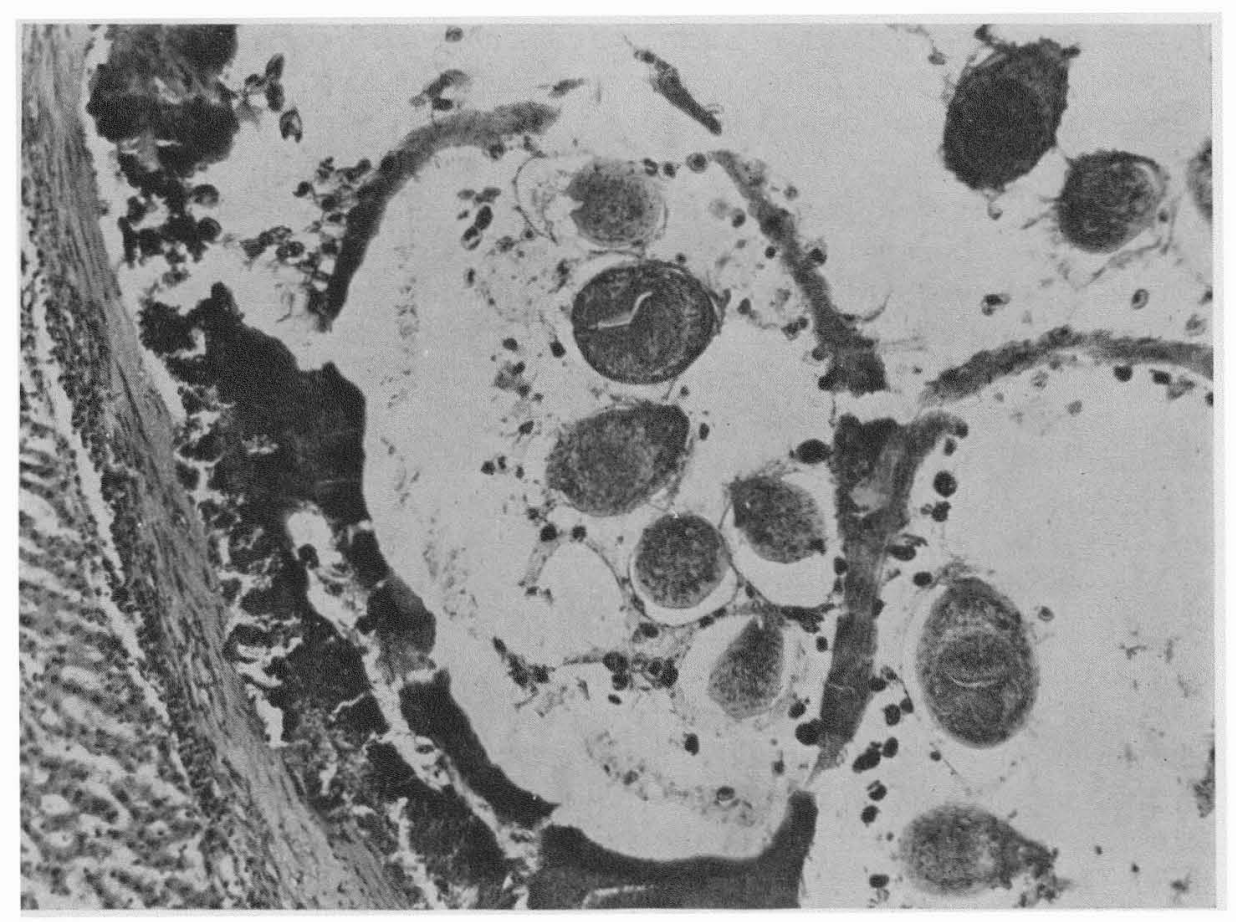

Fig. 6. Histological section of gross specimen in Fig. 5, showing details of structure. Normal liver tissue in lower left corner. Photographed at magnification of $100 \mathrm{X}$.

Considerable information is available on anomalous larval development in some of the domestic animals; these differ in degree of susceptibility to infection.

\section{Alveolar echinococcosis}

In some parts of the world (Bavaria, Tyrol, Russia) larvae of Echinococcus have been reported in which the structure and method of growth differ greatly from that described above. When man is infected with this form the resulting disease is usually known as alveolar echinococcosis or alveolar hydatidosis. There is no development of spherical, well circumscribed larval vesicles, but instead the larval mass consists of a dense aggregation of small cavities (Figs. 5-6). Larval growth takes place as a progressive irregular invasion of the host tissue.

The status of alveolar echinococcosis is somewhat indefinite, but since this form is much the more malignant of the two, and since it has been reported from Siberia (Pavlovskiy, 1946) and St. Lawrence Island, some discussion is necessary here. It may prove to be a serious problem in the north. There are two main theories on the disease: first, that two different diseases exist, caused by different species of Echinococcus; second, that there are two larval forms of the same species, which cause different tissue reactions.

In a recent work, Henschen and Bircher (1945) have concluded that alveolar echinococcosis is caused by the larvae of another species of Echinococcus, which they designated as Taenia echinococcus alveolaris as opposed to 
T. echinococcus bydatidosus (Taenia-Echinococcus). These writers claimed that the adult cestodes of the species producing the alveolar larvae could be differentiated on a morphological basis.

On the other hand, Wardle and McLeod (1952) stated: "The restricted geographical distribution of the infestation has induced suppositions that the adult worm-which has been reared by several observers in dogs-is specifically distinct from granulosus; but the zoological evidence to that effect is not convincing, and it is noteworthy that no investigator has succeeded in provoking alveolar hydatidosis in experimental animals".

Alveolar hydatidosis has, however, been produced regularly in the Arctic Health Research Center laboratory by feeding Ecbinococcus eggs, taken from arctic foxes and dogs on St. Lawrence Island, to certain rodents (especially voles). It is clear from the results of infection experiments that the species of cestode occurring on St. Lawrence Island and Ostrov Beringa (Bering Island) is immunologically different from E. granulosus. Consequently, I am of the opinion that alveolar hydatidosis is caused by a distinct species of Echinococcus. The adult worms have not been differentiated morphologically, and this may not be possible. It is noteworthy that this species does not occur on the continent of North America unless recently introduced through the transport of infected dogs. In the voles primary infection is always in the liver. There is, however, metastastic spread of larval elements to new foci, and this may result in gencralized infection. Experimental infection of voles in the laboratory has shown that nearly completc liver destruction may occur, resulting in the death of the host. This has been discussed in more detail by Rausch (1952).

In the alveolar type of infection a malignant invasion of a given organusually the liver in man-takes place, with the result that the tissue is destroyed and replaced by the parasite tissue. According to Henschen and Bircher (1945) alveolar type larvae usually localize in the subdiaphragmatic zone of the right lobe of the liver. In man the centre of the larval mass often becomes necrotic, producing a cavity which may have a capacity of as much as 6 litres. I have not had any human material for study, but I have not observed this necrosis in experimental animals. Henschen and Bircher have discussed the pathogenicity of this form in detail. They mentioned that new foci of infection may originate through metastasis.

\section{Diagnosis and treatment}

Human hydatid infection may be diagnosed in several ways. Roentgenological examination may disclose the presence of the larvae under favourable conditions. Diagnosis by this method has been discussed by Godfrey (1937). Serological tests are valuable, particularly when used in conjunction with other diagnostic aids. The intradermal Casoni test, using non-specific antigen, is relatively accurate, as is the complement fixation test. The latter, however, requires good facilities. Clinical symptoms may be important, 
depending on the localization of the larva. The need for better knowledge and diagnosis of this disease has been shown in Alaska, where recently several cases of pulmonary infection have been erroneously diagnosed as tuberculomata, and surgical treatment was consequently inappropriate.

Treatment consists of surgical removal of the larval mass. This is ordinarily feasible when E. granulosus is involved, but in some cases the operation is difficult or impossible because of the location of the parasite. The larval mass is dissected free and removed entire. Some advocate the withdrawal of some of the fluid and its replacement with 10 per cent formalin to sterilize the organism before removal is attempted; this may be dangerous. In any event, great care must be taken to prevent perforation or rupture of the larva. Loss of fluid may cause anaphylactic shock, and there is also danger of recurrent growth of the organism from generative elements contained in the escaping fluid. In the latter case, recurrence of the disease may be expected within five to ten years. In inoperable cases the prognosis is grave.

Most cases of the alveolar form are considered inoperable. Treatment might be possible with an early diagnosis, but the prognosis is usually poor. Diagnosis of this form is difficult, since it can be mistaken for carcinoma or other non-parasitic conditions. The surgical treatment of alveolar hydatid disease is discussed in detail by Henschen and Bircher (1945). They advocate a radical resection of the infected hepatic lobe in cases where the larva is somewhat isolated, and a scries of operations for the gradual eradication of the larval mass if it is diffuse.

\section{Occurrence in northern countries}

In attcmpting to compile information on the occurrence and importance of hydatid disease in northern countries, $I$ have found that records are often scarce or difficult to obtain. The scarcity of records from some countries (such as Finland), would seem to indicate lack of knowledge or inadequate medical facilities rather than any rarity of the parasite. This is particularly the casc when dealing with nomadic populations and remote regions. Alaska is a good example of the latter, having a population of a few hundred thousand people scattered over a vast country, with medical service available to a small proportion only of the total. A similar situation exists, apparently, in northern Canada, Lapland, and Siberia. Although important omissions probably exist, I shall attempt to survey the occurrence of hydatid disease in man and lower mammals in all northern countries.

\section{Russia}

Hydatid disease is of frequent occurrence in Russia, if one may judge from the numerous titles which have appeared during the last few years in the Russian medical literature. Most of these works have been concerned with the clinical aspects of the disease, and I have not obtained any papers which give detailed information on distribution and incidence of human infection. References to hydatid disease in Russia are frequent in the European literature. 
Pavlovskiy (1946) devoted ten pages (pp. 330-9) in his book on human parasites to the general discussion of hydatid disease, with particular reference to control. I have not obtained any other recent Russian book on helminthology.

Söderhjelm (1946) has reviewed much Russian literature not available to me. According to him: Romanovitch (1913) observed Echinococcus larvae in reindeer in the arca around Tobol'sk; Grühner (1924; cited after Skrjabin, 1931) reported the larvae from reindeer from the Yakutsk region, the Chukotskiy Poluostrov (Chukotsk Peninsula), and Kamchatka; Skrjabin (1931) recorded the parasite from reindeer around Arkhangel'sk and Okhotsk; Vinogradov (1933) reported a case from the Kol'skiy Poluostrov (Kola Peninsula).

Pavlovskiy (1946) stated that human cases of alveolar echinococcosis were observed yearly in Irkutsk (eastern Siberia). Barabash-Nikiforov (1938) found almost 50 per cent of the red-backed voles (Cletbrionomys rutilus) on Ostrov Beringa to be infected with the alveolar larvae. Afanas'yev (1941) concluded that C. rutilus was the only intermediate host of "Echinococcus granuloszs (Batsch)" on Ostrov Beringa.

Pavlovskiy emphasized the occurrence of the disease on the collective and state farms where sheep werc raised, and it is evident that the problem in its classical cycle of $\operatorname{dog}$ and sheep as the two hosts exists in the regions of Russia where this industry is important.

\section{Finland}

The status of hydatid disease in Finland is not known. According to Mr. Fero Muroma, Game Biologist, Finnish Institute for Game Research, hydatid disease "is very rare in our country" (personal communication). A recent list of parasites occurring in wildlife (Muroma, 1951) does not include E. granulosus. On the other hand Söderhjelm (1945) reported two cases of pulmonary echinococcosis confirmed in evacuees from Finland, and noted that the disease had probably not been previously recorded from the country. He stated (1946) that evacuees from Lapland had told him of finding larvae in reindeer from the vicinity of Enontekiö, and since reindeer are infected in Russia it would be unlikely that the reindeer in Finnish Lapland would have cscaped. Further, the regular use of dogs in herding reindeer in Lapland would seem to ensure good conditions for the completion of the life cycle of Ecbinococcus. Further investigation is needed.

\section{Nomay}

Hydatid disease in Norway appears to be restricted to the regions where reindecr are kept. Harbitz (1913, cited by Söderhjelm, 1946) stated that since 1859, when the first observation on echinococcosis was made in Norway, several cases had been observed in reindeer, particularly from the Tromsö district. Hellesnes (1935, cited by Söderhjelm, 1946) reported infected reindeer from Sjåk, Lom, and Böverdalen in southern Norway. Pulmonary infection in reindeer from Karasjok in northern Norway was mentioned by Qvigstad (1941). I have not found any record of infected Norwegian 'elg' (Alces; called moose in North America), although it might be expected to be an intermediate host of this parasite, as it is in North America. 
Sweden

The occurrence of hydatid disease in man and reindeer in Sweden was reviewed by Söderhjelm (1945), and the following records are taken from his work. Since 1938, when the first case of human pulmonary infection was reported, a total of 40 cases has been diagnosed in the Sandträsk sanatorium. These were all thought to have originated in Norrbotten län (Norrbotten province). Since the known ratio of liver to lung occurrence is approximately 70 to 20 , it was concluded that a much larger number of undiagnosed liver infections must exist.

Among 60 reindeer slaughtered in Kuuri, near Kåbdalis, in 1941, 3 animals had lung infections; while among 70 slaughtered in 1944, 7 infected animals were recorded. In the same year no infected animals were found among 31 calves and yearlings killed at Laver. Among 20 forest reindeer (skogsrenar) killed in 1941 at Rödingsträsk one infected animal was found. However, no infections were noted among 300 forest reindeer killed in 1945.

\section{Iceland}

The highest incidence of human infcction so far reported from the northern hemisphere existed in Iceland during the early part of the last century. There is some disagreement of data, in view of the methods used, but it is apparent in any case that a very grave situation existed. Schleisner (1849, cited by Dungal, 1946) estimated that one out of 7 persons appeared to be infected (based on the examination of 326 patients). It should be pointed out that these figures are based on cases which were clinically diagnosed, and consequently the total figures should be grcater becausc of the large number which would remain undetected. Finsen (1874, cited by Dungal, 1946) found 298 persons infected in an examination of 7,044, or one out of every 22.6 persons. Finsen thought this figure too high, and estimated that actually only about one out of 50 persons was infected. Bjarnhjedinsson (1905) reported on the incidence of hydatid disease in autopsies carried out at the leprosy hospital at Reykjavik; he observed larvae in 26 out of 86 people examined. Dungal (1946) reported on a total of 1,231 autopsies made over a 15-year period (1930-44). Sixty cases of hydatid disease were noted (one of every 20.5 persons). Dungal concluded that the incidence of infection increased with age, and that one of every 6 persons over 60 years of age was infected.

Ofeigsson (1937) stated that the incidence of infection in Iceland had greatly diminished. On the other hand the data presented by Dungal indicate that the problem is still an important one.

\section{Canada}

According to Magath (1950) the first recognized native-born case in Canada was observed in Quebec in 1900. Since that time, enough information has been assembled to show that the parasite has a wide distribution, and it has recently become apparent that the disease may be important in some of the more northern parts of the Dominion.

In 1937 Magath (1937), on the basis of 482 North American human cases for which information was available, was able to determine that only 3 persons 
had been infected in Canada. He concluded that most Canadian cases involved immigrants (particularly from Iceland) who had been infected in other parts of the world. The same writer later reported (1950) that about 700 cases had been diagnosed in North America. Regarding hydatid disease in Canada, he wrote: "James and Boyd stated that hydatid disease was comparatively common in Canada, Iceland and Australia and that it was particularly common in Manitoba on account of the large number of Icelandic immigrants in the province. From table 6 it can be seen that hydatid disease was never common in Canada and in the past twenty years only 9 cases have been reported, and only 3 from Manitoba. Truman said that 35 cases had been diagnosed in Winnipeg General Hospital between 1923 and 1942, but of these only 2 have becn reported so far as I can determine. Hydatid disease has disappeared from Iceland and the Icelandic immigrants to Canada have almost all died".

Wild animals in Canada are often parasitized by E. granulosus. Hadwen (1932) reported E. granulosus from moose, Alces alces [sic], at The Pas, Manitoba. Law and Kennedy (1933) also reported it from the moose. More recently, de Vos and Allin (1949) collected this parasite from three moose killed in northwestern Ontario and noted that "the digestive tracts of most timber wolves from northwestern Ontario examined last winter contained tapeworms. Ecbinococcus granulosus was the most common species recovered. ..".

The occurrence of Echinococcus larvae in North American wild mammals, has been reviewed by McTaggart Cowan (1948). He reported larval cestodes from black-tailed deer, Odocoileus bemionus columbianus, taken at Crofton, Vancouver Island, and from mule deer, O. b. bemionus, and elk, Cervus canadensis nelsoni, in Jasper and Banff National Parks. Infected wolves were also reported. Dr. McTaggart Cowan kindly lent me specimens from these animals, and cxamination showed that all have the typical larvae of E. granulosus. Banfield (1952) observed the larval stage of E. granulosus in the lungs of two barren ground caribou out of 54 critically examined.

Though relatively few, these records indicate that $E$. granulosus is widely distributed in Canada. Whether or not it is an important human parasite remains to be determined. The Department of National Health and Welfare is currently conducting a survey of this disease, and it is anticipated that their results will do much towards making known its importance to human health.

Alaska

Farly records of the occurrence of E. granulosus in Alaska are few. Hadwen and Palmer (1922), in a footnote, stated that Tacnia echinococcus (=E. granulosus) was found in Alaskan dogs in 1914 by E. C. Joss, U.S. Bureau of Animal Industry. Hadwen and Palmer also mentioned this parasite in connection with their Alaskan reindeer investigations but did not give any specific locality rccords. They did, however, state that the cestode larvae were not found in St. Lawrence Island reindeer.

The first Alaskan record of hydatid disease in man appears to be that of Magath (1941). Williams (1948) reported the occurrence of a pulmonary 
infection in an Indian woman from the upper Tanana region. Human cases are being diagnosed rather frequently in the native population in Alaska. It is to be expected that many more will be found with increasing awareness that the disease occurs in the Territory.

In early 1949 the Animal-borne Disease Branch of the Arctic Health Research Center at Anchorage undertook the investigation of hydatid disease and related problems in Alaska among the animal population. This work has been continued on a Territory-wide basis since that time, with the result that considerable information has been accumulated. A detailed report will be published separately, but a few general remarks will be included here.

It has been found that moose are conmonly infected with E. gramulosus in some localities. This animal appears to be the important intermediate host, and probably serves as the main source of infection for canine animals over much of the Territory. So far I have examined only one infected caribouan old bull killed near the Black River, north of Nelchina. Mountain sheep may sometimes serve as the intermediate host of E. granulosus, but I have no information on this point despite the examination of a good series of these animals.

Canine animals, both dogs and the wild species, frequently harbour the adult cestodes. As many as twenty-five per cent of the dogs in some of the arctic villages may be infected, and more than 10 per cent of all Alaskan wolves examined harboured the adult cestodes. Infected coyotes so far have not been observed, but the series examined has been relatively small.

On St. Lawrence Island the cycle involves two species of microtine rodents, Microtus oeconomus innuitus Merriam and Clethrionomys rutilus albiventer Hall and Gilmore. The arctic fox is the main final host, but infected dogs are not uncommon. The characteristics of the life cycle and cpizootiology of the cestode on St. Lawrence Island have been discussed in other publications (Rausch and Schiller, 1951; Rausch, 1951, 1952). It is of unusual interest that this cestode is identical in its life cycle characteristics with that reported on Ostrov Beringa by Barabash-Nikiforov (1938) and Afanas'yev (1941). Although both authors referred to it as E. gramulosus, it is obviously not this species. I have no doubt that it is identical with the St. Lawrence Island species, but it is not possible at present to assign a specific name'.

\section{Animal cycles involved in hydatid disease}

Before control measures can be considered, an understanding of the epidemiology of hyatid disease is necessary. Human infection results from close association with canine animals harbouring the adult cestodes, but the interrelationships involved may be quite complex. Man's control of certain animals may adjust their behaviour to the point that conditions for survival of the parasite are optimum (e.g., the reindeer-dog association brought about

1 A vole infected with Echinococcus larvac has recently been obtained by Dr. Jean G. Baer, Université de Neuchâtel, Switzerland (personal communication). This is of special interest in connection with the frequent records of alveolar disease from south Germany and Switzerland. 
through usual husbandry methods). Four major categories of animal associations may be differentiated in northern countries; these are discussed briefly.

1. Cycle involving dogs and sheep

In Iceland, as well as in parts of Russia, dogs and sheep are involved in the life cycle of E. granulosus. Infected dogs kept constantly with the flock disseminate many eggs which are ingested by grazing sheep. Dogs, in turn, are infected by eating sheep viscera containing the larval cestodes.

Human infections occur frequently under such conditions, as is shown by the situation in Iceland. This does not always result, however, from a direct transmission. The surface of the ground may be heavily contaminated by dog feces, and sheep lying in the area often have many eggs adhering to their wool. Pavlovskiy (1946) pointed out that the incidence of infection among the women, who are concerned with shearing and otherwise caring for the sheep, is significantly greater than among the men. The eggs also adhere to the fur of dogs, from which they may be transferred to the hands of those having contact with them, or they may fall off inside the dwellings. Dogs gentle enough to associate with children transfer eggs through licking the face and hands during play. Eggs can be carried into the house on footwear or equipment. The threat of human infection under such conditions is constant.

\section{Cycle involving dogs and reindeer}

Hydatid disease is connected closely with reindeer management in northern Norway, Sweden, and Finland. This has also been the case in a few places in Alaska. Although the reindeer may ingest eggs directly while feeding, other modes of infection no doubt exist. Söderhjelm (1946) suggested that reindeer may ingest cestode eggs when they eat snow soaked with dog urine, and that the urine of female dogs especially might dislodge eggs from the perianal region. The eating of urine-soaked snow for its salt content is a well known habit. Since the snow would often be eaten within a short time it is likely that the eggs would escape damage from low temperatures.

Under present conditions in Lapland up to 10 per cent of the reindeer of certain herds may be infected. There appears, however, to be less opportunity for human infection than in the dog-sheep cycle.

\section{Cycle involving wild and domestic canids and wild ungulates}

In boreal North Amcrica (from the northern boundary of the United States) E. granulosus is a ubiquitous parasite of wild canine animals and ungulates, and several different cycles of infection probably exist. Since reported by Riley (1933) from moose in Minnesota, its occurrence in this animal has been more-or-less emphasized. The moose apparently serves to transmit the parasite to dogs as well as to wild canids over much of Canada and Alaska. For instance in the vicinity of Palmer, in the heavily cultivated Matanuska valley, almost every aged moose is infected, and I estimate that the larvae may be found in at least 50 per cent of the adult animals. Wolves are rare or absent in the Palmer area, so other species must serve as the final host. In view of their method of feeding, it is surprising that moose have much 
opportunity to ingest eggs. Investigation of the mode of natural infection of moose would be worthwhile. I have no positive information on occurrence of Echinococcus larvae in moose in Eurasia. A recent paper by Machul'skiy (1950) on the parasites of moose in Buryat-Mongoliya does not mention any species of Ecbinococcus.

Although caribou are much more abundant than moose and their feeding habits would seem to be conducive to picking up Echinococcus eggs, infected caribou are relatively few. Of more than 200 caribou examined, I have observed only the one infected animal mentioned above. Eskimo in the Brooks Range have, however, told me of finding structures in the lungs of caribou which almost certainly were Echinococcus larvae.

In the Anaktuvuk Pass region of the central Brooks Range wolves commonly harbour the adult parasites. Of the 121 wolves I examined 25 per cent were infected. Both wolf and caribou occur on the same range. Since wolves very rarely capture caribou which are not diseased or otherwise weakened, it must be assumed that aged animals make up a large proportion of their kill. Consequently, the chances for wolf infection would be enhanced. I wish to emphasize though that the fact that the wolf is involved in the life cycle of this cestode does not constitute any appreciable threat to human health and this information should not be construed as support for those in favour of generalized wolf destruction.

Both red and arctic foxes are host to E. granulosus in Alaska. The way in which foxes obtain infected viscera of ungulates is not known with certainty; presumably, from time to time, they find carcasses from which they feed. Infected foxes have little importance as far as man is concerned. There might be some risk involved for trappers skinning infected animals, and it is possible that edible vegetation might be contaminated by fox feces.

The only real threat to human health comes from infected dogs. In the outlying villages where dogs provide the sole means of transport, large numbers are tethered in the immediate vicinity of the dwellings. The children play among them, where fecal contamination of the ground is massive. It is not uncommon for frozen meat or fish to be stacked on the ground round the houses, where it may be urinated upon by untethered dogs. This urine might contain eggs. In summer, freshly killed meat of caribou or moose often has considerable contact with the ground before being cached. In addition to the eggs carried into the dwellings on footwcar and other articles, they may be brought in on the fur of the dogs themselves. In some places the dogs come freely into the houses; in other villages only bitches with small puppies are permitted inside. The crossbar of the dog harness is almost always much soiled by excreta. Hence there is opportunity for direct contamination of the hands and clothing whenever the animals are harnessed, often by the girls and women, or when harnesses are taken inside for repair.

It is evident that ample opportunity exists for the ingestion of the costode eggs during the course of everyday activity in Eskimo and Indian villages. Water contamination is still another means of egg dissemination. According to Pavlovskiy (1946) the eggs of E. granulosus survive up to 10 days in water. 
4. Cycle involving wild and domestic canids and mouse-like rodents (Microtus and Cletbrionomys)

This relationship is the least known, having only recently been recognized as distinct. It has been discussed above, and need not be considered further here.

\section{Control}

Control of hydatid disease depends on the elimination of infected dogs. The required program is largely one of prophylaxis, since human infections are better prevented than treated. Certain procedures are appropriate in attempting to reduce the number of human cases through dog control and sanitation. The main points of the control program put into effect in Iceland were enumerated by Ofeigsson (1937). Those which have general value are listed here: "Better hygiene; the rapid spread of the knowledge of the life cycle of the parasite among doctors and laymen, who realize the importance of breaking the cycle; more and better doctors; laws forbidding all unnecessary dogs; a quarantine once or twice a year, of all dogs during which they would be treated with baths and suitable drugs; warnings to people against too much petting of their dogs and careful washing of their hands after touching them."

It is evident that improved sanitary conditions, destruction of excess dogs, and education of the people are important procedures in the control of hydatid disease. Remedial programs appear to be in effect in most of the northern countries where the importance of the disease has been recognized for many years. In the remote regions of Eurasia-Lapland and Siberia-it appears that much is yet to be done.

In Alaska and parts of Canada, where the disease is receiving attention for the first time, little progress has been made towards initiating a control program. The Alaskan Command has put into effect an order prohibiting the export of all dogs from St. Iawrence Island and the arctic coast regions of Alaska by members of the military forces. A similar quarantine regulation for civilians is being prepared by the U.S. Public Health Service. One of the most important things is to prevent the St. Lawrence Island form of Ecbinococcus from being introduced into continental North America.

The lack of adequate medical assistance, combined with poverty, poor diet, and a low level of education contribute towards a high morbidity in aboriginal people in Alaska. It may be premature to attempt to control a disease of the relatively small importance of echinococcosis until tuberculosis is brought under control. Fortunately, improved sanitary conditions will affect both. One cannot hope that the living standards of Alaskan Eskimo and Indians will immediately improve, but it would be possible, through public health education, to lessen the importance of hydatid disease. There is need throughout Alaska for drastic reduction of worthless dogs; this would affect rabies as well as hydarid disease, and would conserve much food which could be utilized by the human population. Legislation appears to be the only means by which this could be brought about. Through education it would not be difficult to create an understanding of the dangers of feeding infected 
animal parts (e.g. moose and caribou lungs, etc.) to dogs. Further, dogs should be tethered at a reasonable distance from human dwellings; along the coast the gravel beaches would be a most suitable place. Although no antihelminthic is known which can be depended upon to eliminate all the adult parasites from the intestine of dogs, periodic treatment would at least reduce the infection. On St. Lawrence Island measures would be necessary to prevent the dogs eating the voles. Again, keeping the dogs tethered and on the gravel beaches would assist this, since the rodents rarely leave the cover of vegetation.

There is need for making the situation known to medical practitioners. The majority of physicians trained in the United States are not adequately familiar with hydatid disease, since it is given little more than passing mention in most medical schools. Contrary to the current opinion, it should be recognized that echinococcosis is of importance in North America. Medical workers should especially be aware of the consequences if alveolar hydatid disease were to become established in continental North America.

\section{References}

Afanas'yev, V. P. 1941. "Parazitofauna promyslovykh mlekopitayushchikh Komandorskikh Ostrovov". Uchenye Zapiski, Ser. Biol. Nauk, Vol. 18, pp. 93-117.

Banfield, A. W. F. 1952. "The Canadian barren-ground caribou investigation". Paper read at the Third Alaskan Science Conference, 22-27 Scptember 1952.

Barabash-Nikiforov, I. 1938. "Mammals of the Commander Islands and the surrounding sea". J. Mammal. Vol. 19, pp. 423-9.

Bjarnhjedinsson, S. 1905. "I.es kystes hydatiques et les lépreux en Islande". Lepra. Biblioth. Internat. Vol. 5, pp. 141-3.

Dew, H. R. 1925. "The histogencsis of the hydatid parasite (Taenia echinococcus) in the pig". Med. J. Australia, Vol. 1, pp. 101-10.

1928. 'Hydatid discase'. Sydney, Australia.

de Vos, A. and A. E. Allin. 1949. "Some notes on moose parasites". J. Mammal. Vol. 30, pp. $430-1$.

Dungal, N. 1946. "Echinococcosis in Iceland". Amer. J. Med. Sci. Vol. 212, pp. 12-17.

Ficbiger, J. 1947. 'Die ticrischen Parasiten der Haus- und Nutztiere, sowic des Menschen'. Vienna: $436 \mathrm{pp}$.

Godfrey, M. F. 1937. "Hydatid disease: clinical, laboratory and rocntgenographic observations". Arch. Internal Med. Vol. 60, pp. 783-804.

Hadwen, S. 1932. IUntitled note on moose parasitesl. Proc. Helm. Soc. Wash. in J. Parasit. Vol. 19, p. 83.

Hadwen, S. and I.. J. Palmer. 1922. 'Reindeer in Alaska'. U.S. Dept. Agri. Bull. No. $1089,74 \mathrm{pp}$.

Henschen, C. and R. Bircher. 1945. "Zur Epidemiologie, Pathologie und Chirurgic des Ecbinococcus alveolaris". Bull. Schweiz. Akad. Med. Wiss. Vol. 1, pp. 209-80.

James, E. and W. Boyd. 1937. "Fichinococcus Alveolaris (with the report of a case)". Can. Med. Ass. J. Vol. 36, pp. 354-6.

Law, R. G. and A. H. Kempedy. 1933. "Echinococcus granulosus in a moose". North Amer. Vet. Vol. 14, pp. 33-4.

Machul'skiy, S. N. 1950. "Gel'minty losey Buryat-Mongolii". Doklady Akad. Nauk S.S.S.R. Vol. 73, pp. 1313-5.

Magath, T. B. 1937. "Hydatid (E.chinococcus) disease in Canada and the United States". Amer. J. Hygiene, Vol. 25, pp. 107-34.

1950. "The present status of hydatid (Echinococcus) disease in North America". Arch. Internac. Hidatidosis, Vol. 11, pp. 193-203. 
McTaggart Cowan, I. 1944. 'Parasites, diseases and injuries of game animals in Banff, Jasper and Kootenay National Parks'. Nat. Parks Bur., Dept. Mines and Resources, Canada. Mimeo. $42 \mathrm{pp}$.

1948. "The occurrence of the granular tape-worm Echinococcus granulosus in wild game in North America". J. Wildl. Man. Vol. 12, pp. 105-6.

Mönnig, H. (). 1938. 'Veterinary helminthology and entomology'. Baltimore: 409 pp.

Muroma, Fero. 1951. "Suomen tärkcimpien riistaeläinten loiset ja taudit tähän mennessä Suoritettujen tutkimusten mukaan". Suomen Riista, Vol. 6, pp. 159-62.

Ofcigsson, O. J. 1937. "Hydatid disease in Iceland". Proc. Staff Meet. Mayo Clin., Vol. 12, pp. $420-1$.

Pavlovskiy, Ye. N. 1946. 'Rukovodstvo po parazitologii cheloveka'. Vol, 1. Izdatel'stvo Akad. Nauk S.S.S.R., Moscow: 521 pp.

Qvigstad, J. 1941. 'Den tamme rens sykdommer'. Tromsó Mus. Arsh. Naturbist. Vol. $59,56 \mathrm{pp}$.

Rausch, R. 1951. "Biotic interrelationships of helminth parasitism". Public Health Repts. Vol. 66, pp. 928-34.

1952. "Studies on the helminth fauna of Alaska. XI. Helmintl parasites of nicrotine rodents--taxonomic considerations". J. Parasit. Vol. 38 (in press).

Rausch, R. and E. I. Schiller. 1951. "Hydatid disease (Echinococcosis) in Alaska and the importance of rodent intermediate hosts". Science, Vol. 113, No. 2925, pp. 57-8.

Riley, W. A. 1933. "Reservoirs of Echinococcus in Minnesota". Minn. Med. Vol. 16, pp. $744-5$.

Schlcisner, P. A. 184\%. 'Island undersögt fra et legevidenskabeligt Synspunkt'. Copenhagen.

Soderhjelm, I.. 1945. "Förekonsten av Fichinococcus bydatidosus hos människa och ren (Rangifer tarandus)". Svenska Läkartidningen, Vol. 28, 7 pp.

1946. "Echinococcus bydatidosus hos ren (Rangifer tarandus)". Skandinavisk Veterinärtidskrift, pp. 378-81.

Truman, K. R. 1942. "Hydatid cyst of the lung". Manitoba Med. Rer: Vol. 22, pp. 27-8.

Wardle, R. A. and J. A. McI cod. 1952. 'The zoology of tapeworms'. Minneapolis: $780 \mathrm{pp}$.

Williams, R. B. 1948. "Echinococcosis or hydatid discase". Alaska's Health, Vol. 6, p. 6. 